\title{
Transitional Justice in Iraq after 2003
}

\author{
Mohammed Ihsan* \\ Department of Defense studies, UK
}

*Corresponding author: Mohammed Ihsan, Senior research follow , king's College London, defense Studies department and President of International University of Erbil, Kurdistan

\section{Introduction}

Any country emerging from a period of prolonged dictatorship must undertake structural reforms to its justice system and procedures. In Iraq, reforms have taken place around five key thematic axes: Criminal justice; institutional reform; victims' reparations; truth and memory; and gender justice. The main aims of these measures were to build trust among the population, to strengthen institutions, to provide material compensation for those who suffered under Baathist rule, and to restore dignity and shared values among all peoples of Iraq. Transitional justice offers a promise: it gives a country the opportunity to deal with its past and shape its future. In a 2004 report the UN Secretary General [1] defined transitional justice as "the full range of processes and mechanisms associated with a society's attempt to come to terms with the largest scale past abuses in order to ensure accountability, serve justice and achieve reconciliation".

In March 2002, I joined several Iraqi experts working with the US State Department (The Iraq Working group) preparing scenarios for post Saddam Iraq. That report [2] outlined a transitional justice plan which would attempt to transform "an unstable, chaotic state caused by a dictatorship with a legacy of gross human rights abuses into a democratic pluralistic system which respects the rule of law." To that end, the report insists that "building a future on the basis of respect for the rule of law requires a thorough review of the system of laws left behind by this regime to identify, remove and/or replace those provisions which violate internationally recognized basic human, civil and political rights." In this paper, I examine whether Iraq has managed to achieve reconciliation or serve justice to its people through the transitional justice measures enacted in the post-regime era.

\section{Criminal Justice}

Regarding criminal justice, Coalition Forces established the Iraq Special Tribunal, in order to indict the 52 top ranking Iraqi officials, including Saddam Hussein for crimes committed between 17 July 1968 and 1 May 2003.

In 2005, the Iraqi Authority issued Law Number 10, which changed the status of the Special Tribunal to a permanent national institution, the Iraqi High Criminal Court [3]. While the court had previously dealt exclusively with genocide crimes, crimes against humanity and war crimes, this new institution had the broad mandate to prosecute "Violations of Iraqi Law". It was the first court in the Middle East to prosecute a head of state and was the first legal institution in the history of the region which combined international law with national law. But because of political and sectarian interference in the application of court procedures in Iraq, parties with vested interests prevented the court from upholding and applying the law equitably. The sentences of the court were not appropriate or proportional for the crimes committed. While some high-ranking government officials were indeed prosecuted for crimes including genocide, the number of those brought to justice pales in comparison to the thousands of victims who suffered under Baathist rule.

Table 1:

\begin{tabular}{|c|c|c|}
\hline $\begin{array}{c}\text { Crimes } \\
\text { Committed }\end{array}$ & $\begin{array}{c}\text { Agencies participated in the } \\
\text { Crimes }\end{array}$ & $\begin{array}{l}\text { No. of Final } \\
\text { Verdicts }\end{array}$ \\
\hline $\begin{array}{c}\text { Arabization } \\
1963-2003\end{array}$ & All government agencies & 8 \\
\hline $\begin{array}{c}\text { Faylee Kurds } \\
1970-1991\end{array}$ & $\begin{array}{c}\text { Security, Baath Party, Mukhbarat } \\
\text { agencies }\end{array}$ & 5 \\
\hline $\begin{array}{c}\text { Barzanis } \\
\text { Genocide } 1983\end{array}$ & Security and Republican Guards & 4 \\
\hline $\begin{array}{l}\text { Anfal Campaign } \\
\text { (1986-1988) }\end{array}$ & $\begin{array}{c}\text { Armed Forces, Security, } \\
\text { Intelligence and Baath Party } \\
\text { agencies }\end{array}$ & 6 \\
\hline $\begin{array}{l}\text { Halaja (Chemical } \\
\text { Attack)1988 }\end{array}$ & $\begin{array}{c}\text { Military, Air Force and Baath Party } \\
\text { agencies }\end{array}$ & 4 \\
\hline
\end{tabular}


The responsibilities and verdicts for the crimes committed against Kurds and investigated by the Court are a case in point: (Table 1) Meanwhile, Sunni political parties sought to cast Saddam Hussein as the sole perpetrator of crimes in Iraq without holding the state structures responsible, while most Shiite parties lobbied for harsh sentencing of accused Sunni criminals to leverage political gain. The criminals themselves used the media to mobilize supporters to create more chaos in Iraq and sow seeds of instability for the nascent democratic state. Moreover, coalition forces implemented a series of decisions which encompassed a policy of De-Baathification. Through these legal procedures, individuals above a certain rank in the Baath party were summarily fired from their jobs and banned from holding any public-sector post in the future.

Specifically, Coalition Provisional \authority (PCA)Decree Number 1, issued on 16 May 2003, sought to disassemble Ministry of Culture and Information, and purge all media institutions. CPA Decree Number 2 issued 23 May 2003 purged the Ministries of Interior, Defense and Intelligence. With these policies, the CPA government cast all Baath party members in the same light, without distinguishing between those who had committed crimes and those who had not. Approximately 500,000 employees of these state organs were dismissed with a single pen-stroke, sent home without compensation or pensions. Doctors, professors, police officers and civil servants many of whom had committed no crimes but were affiliated with the Baath party to secure jobs under the previous regime were uniformly targeted and banished from the state-building process. Five months after the Coalition Forces took Baghdad, Iraq's unemployment rate had reached 67\% [4].

As a result, many intellectuals who could have contributed to institution building during this crucial transitional period left Iraq, moving to neighboring countries or seeking refuge abroad. With these decrees, what had begun as a process of transitional justice soon became a tool for group revenge: rather than taking a victimfocused approach, de-Baathifcation targeted huge swathes of society without due process, to the detriment of the reconciliation process. Many of those who lost their positions became the raw materials from which terrorist groups and militias such as the Mahdi Army drew their recruits in the years to come [5].

\section{Institutional Reform}

Under dictatorship, public institutions such as the police, military and judiciary are often instrumenting of repression, and are used by the regime to perpetrate systematic violations of human rights. Under Baathist rule, all these state organs were coopted by the regime to stifle dissent and centralize power. When transitions to democratic governments occur, reform of these institutions is vital. While the new regime in Iraq made initial efforts to democratize these institutions, they were ultimately recast based on sectarian and party beliefs rather than integrity and public legitimacy. The new Iraqi authorities were not prepared to deeply reform the national legal framework, relying instead on judicial norms and ideologies which had prevailed under the previous regime. For example, several free market policies seeking to court foreign investors have been hobbled by a legal system based on the statist policies implemented under Baathist rule. Until today, Iraq has seen low levels of investment from abroad, largely because the archaic legal system is unable to accommodate the introduction of substantial foreign capital. Mechanisms for fighting corruption are equally absent.

Moreover, reforms of the education sector were similarly feeble in Iraq. While countries undergoing transitional justice should prioritize human rights-based education focused on reconciliation and co-existence, the new authorities in Iraq made few such efforts. The Baathist Sunni education system was replaced with a cobbled together pedagogy lacking standards or oversight, which did little to foster an educated, ethical generation. Today, this vital national institution lacks systematization, ethics and professionalism. A 2018 cheating scandal, in which it was discovered that professors were selling information about the national exam to students, typifies the chaos existing in this ministry today.

\section{Victims Reparations}

In any approach to transitional justice, it is the main responsibility of the state to ensure reparations for the victims of violations committed during the period of dictatorship. Based on Iraq institutions and the national transitional justice plan, the new authorities developed institutions including the Establishment of Martyrs to achieve this. Law number 3 of 2006 which was amended again in 2016, put in place procedures to provide the families of those killed by Saddam (martyrs) with financial packages as part of the reparations process. The children of martyrs were to be allotted plots of land, given social security benefits, grants for the Hajj and even funds to cover wedding expenses. But the budget allocated for such activities was far too small to provide all these promised services to the large number of victims of the Saddam regime. Moreover, corruption has been a systematic issue in the Establishment of Martyrs fund.

Another institution, the Establishment of Political Prisoners in Iraq, was created by law 24 in 2005. The main aim of this law was to restore those who had been unjustly dismissed from their posts by Baathist policies to their jobs and return them back to public offices. But for them and members of their families it created again more bureaucratic chaos: it was unclear who should be compensated and for what period. Moreover, the law did not stipulate which posts should be restored to whom, or what rank they should assume when they were reinstated. As a result, many underqualified individuals assumed high level posts while lacking the requisite experience. This has led to endemic under-performance and a lack of professionalism in crucial government institutions, including the foreign service. 


\section{Truth and Memory}

Acknowledging, addressing, and rectifying crimes committed under dictatorship requires that attention be paid to preserving memory. In Iraqi culture, memory plays a significant role in in the daily lives of citizens: events from years and even generations past is repeated and shared in group settings, which shapes how communities see themselves and how they perceive others. After the fall of Saddam Hussein, the Coalition Forces started a program to preserve memories of the former regime. A Washington-based NGO called the Iraq Foundation spent millions archiving documents, preparing text books, recording oral histories and arranging for public exhibitions for people to acknowledge the collective trauma experienced under Saddam Hussein's dictatorship. Unfortunately, nothing from these programs has been implemented. Carefully prepared materials collected dust on the shelves of numerous ministries in Baghdad after the American withdrawal from Iraq. Instead of opening a dialogue about the crimes committed under Baathist rule which would have allowed grievances to be aired and communities to heal, decades old wounds were hastily bandaged and allowed to fester.

Where truth is concerned, some Iraqis proposed Truth commissions like those implemented in South Africa after the end of Apartheid. But because of the tribal structure of Iraqi society and lack of government direction no perpetrators were prepared to come forward and seek forgiveness from the population. Lacking this testimony, rumors and myths prevailed which led to further retrenchment of different ethnic and sectarian communities. The reconciliation process was severely hampered by the failure of the authorities to create a platform for perpetrators to publicly acknowledge their misdeeds. Moreover, at the time, many political parties representing victims insisted that forgetting the past at least temporarily would help them to secure votes in the next government and avoid creating political enemies. But the victims themselves never forgot: in the years since, kidnappings, murders, revenge and sectarian strife have been fueled by the absence of a public resolution for Saddam-era crimes.

\section{Gender Justice}

During the Baath party era, human rights violations had unique consequences for women. The result of three decades of Baath party rule was 1.5 million widows in Iraq. Thousands of additional women were neither married nor officially widowed, their husbands disappeared in regime prisons or executed and buried in unmarked graves. They were the silent victims of the regime and society. It is difficult for women in a patriarchal society to express themselves and seek help from official channels, and so they suffered quietly. Moreover, thousands of single mothers attempted to raise the next generation of Iraqi citizens without partners. There were no proper programs from the government to address the plight of these women, to restore their dignity or answer questions about the fates of their sons and husbands.

\section{Discussion}

I believe the main reason transitional justice failed in Iraq was since Iraqi nationals were not initially involved in the rebuilding of the country and there were no objective assessments of the process. Any transitional justice measures must soberly analyze the political, social and legal context in the country to determine what steps should be taken when. In Iraq, however, this analysis was conducted subjectively by parties and individuals seeking revenge above national reconciliation. At the same time, victim's groups thought that transitional justice would entirely resolve outstanding grievances and right all past injustices. The authorities failed to communicate to victims that transitional justice must strike a delicate balance between investigating and prosecuting criminal acts and avoiding risks linked to fragility and destabilization.

We should be under no illusion that transitional justice can cure all social ills. The long term social and political struggles for justice and equal opportunities might be assisted by measures of transitional justice, but not solved by it. I believe that many issues Iraq has faced since the fall of Saddam Hussein, including the rise of Al Qaeda and ISIS, conflicts between Erbil and Baghdad and ongoing legal questions surrounding the disputed territories, are due to the failure of transitional justice in the country. Furthermore, even post ISIS if there is no proper transitional justice in Iraq and the failure of the post Saddam transitional justice procedures are not rectified, Iraq will face another civil war and become yet another source of instability in the region and the world.

\section{Recommendations}

I believe that transitional justice should not be procedural in nature, as it has been in Iraq, but should rather seek to bolster trust in public institutions. Instead of ad-hoc policies like those which have been implemented in the post-Saddam era, a coherent roadmap should be developed which can build lasting ties between communities. All approaches to transitional justice should be based on universal human rights rather than on targeted retribution. While each society must choose its own path, only by pursuing forward-looking policies which seek to uphold truth and justice can real social reconciliation be attained.

\section{References}

1. UN Secretary-General (2004) The rule of law and transitional justice in conflict and post conflict societies. UN Doc.

2. Malcolm Byrne (2014) The Battle for Iran, 1953: Re-Release of CIA Internal History Spotlights New Details about anti-Mosaddeq Coup. The National Security Archive.

3. The author worked as International Expert on Genocide for IHCC from 2005-2007 in Baghdad, mainly responsible for gathering evidences for genocide crimes.

4. Klein Naomi (2008) The Shock Doctrine: The Rise of Disaster Capitalism, Penguin, London pp. 342.

5. Ibid pp. 358. 
(C) This work is licensed under Creative

To Submit Your Article Click Here: Submit Article

DOI: $10.32474 /$ PRJFGS.2018.02.000149

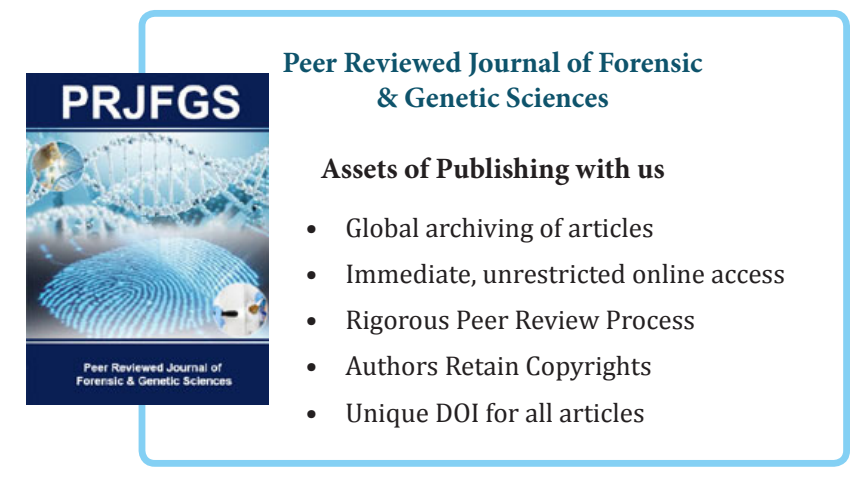

